\title{
IMPLEMENTASI PENDIDIKAN KARAKTER KEPATUHAN DI PESANTREN BUNTET CIREBON
}

\author{
Intan Luwih Yulyana,* Aam Abdussalam, Aceng Kosasih \\ Universitas Pendidikan Indonesia \\ *Email: intanlyulyana1602@gmail.com
}

\begin{abstract}
This study is conducted based on some cases indicating the decadence of morality, especially among teenagers. All this time, Pesantren or Islamic boarding school has been recognized as the appropriate institution to instil student's character. This study aims at finding out the planning, implementation, and education results of the obedience character at Pesantren Buntet Cirebon. This study employs a qualitative-descriptive approach. In addition, the data collection is carried out through observation, interviews, and documentation studies. The result of this study shows that the character education of obedience was implemented through uswatun hasanah (good examples), targib wa tarbib, and story methods. Based on the data found and analyzed in this study, the researchers found that the obedience was considered as an important and natural aspect. This obedience was established sincerely in a long process. In fact, this sincere and natural obedience were influenced by the characters possessed by the kyai, such as sincerity, noble character, sincere affection, and bumbleness towards the santri / students. As a consequence, it resulted in the better religious activity and personality of santri, and this obedience had also an effect on respecting others, such as on the teachers, parents, community, fellow students, and even on the rules of pesantren.
\end{abstract}

Keywords: Character Education, Obedience, Habituation in Pesantren.

\begin{abstract}
ABSTRAK
Penelitian ini dilatarbelakangi maraknya berbagai kasus yang menunjukkan semakin rendabnya moral masyarakat utamanya para remaja. Selama ini, pesantren diakui sebagai lembaga yang tepat untuk membentuk karakter seseorang. Penelitian ini bertujuan untuk mengetahui perencanaan, pelaksanaan serta hasil pendidikan karakter kepatuban di Pesantren Buntet Cirebon. Dengan menggunakan pendekatan kualitatif-deskriptif, pengumpulan data dilakukan melalui observasi, wawancara, serta studi dokumentasi. Hasil penelitian menunjukkan bahwa pendidikan karakter kepatuhan dilakukan dengan metode uswatun hasanah, targib wa tarbib, dan kisah. Berdasarkan data-data penelitian, penulis menemukan bahwa kepatuhan merupakan aspek yang penting dan bersifat alami. Kepatuhan ini terjadi secara tulus yang terjadi dalam proses yang panjang. Terjadi secara tulus dan alami karena kyai memiliki sifat ikblas, akblak yang mulia, kasih sayang yang tulus, dan sifat tidak memaksa tehadap santri. Hal tersebut juga berpengaruh terbadap aktivitas religius dan kepribadian santri yang lebih baik, serta kepatuhan terhadap hal yang lainnya seperti terhadap guru, orangtua, masyarakat, sesama santri dan terhadap peraturan pesantren.
\end{abstract}

Kata kunci: Pendidikan Karakter, Kepatuhan, Pembiasaan di Pesantren. 


\section{PENDAHULUAN}

Pendidikan karakter merupakan suatu hal yang sangat penting untuk diterapkan dalam kehidupan bermasyarakat, karena karakter bangsa merupakan modal dasar untuk membangun peradaban yang tinggi dan maju, masyarakat yang memiliki sifat jujur, kerja sama, mandiri, patuh pada peraturan, dapat dipercaya, tangguh dan memiliki etos kerja yang tinggi, dan akan menghasilkan sistem kehidupan sosial yang baik dan teratur.

Dewasa ini marak berbagai kasus dan hasil penelitian berbagai pihak telah menunjukkan bahwa moral/karakter masyarakat terutama para remaja mulai meresahkan atau dengan kata lain semakin rendah, dan ini disebabkan oleh berbagai faktor.

Untuk membina karakter yang baik, diperlukan suatu lembaga yang dapat memberikan kontribusi lebih untuk membentuk karakter. Dalam hal ini, pesantren merupakan lembaga yang dapat membantu terbentuknya karakter seseorang, karena pesantren merupakan lembaga pendidikan untuk mendapatkan bimbingan, penghayatan, pemahaman, serta pembelajaran ajaran Islam dengan menekankan pentingnya moral agama sebagai pedoman yang dapat diamalkan dalam kehidupan bermasyarakat.

Berkaitan dengan hal tersebut, agar pesantren dapat diminati banyak orang maka pesantren harus memiliki daya tarik/keunikan. Pesantren Buntet Cirebon memiliki banyak keunikan seperti adanya soan, haul, ngaji pasaran, komunitasnya yang homogen, dan lain sebagainya. Pesantren Buntet Cirebon juga terkenal dengan adabnya yang baik dan kepatuhan terhadap kyai yang begitu melekat, sehingga dilakukan penelitian yang terfokus pada pendidikan karakter kepatuhan di Pesantren Buntet Cirebon.

\section{METODE PENELITIAN}

Pendekatan yang dilakukan dalam penelitian ini adalah pendekatan kualitatif-deskriptif dan pengumpulan data dilakukan melalui observasi, wawancara, serta studi dokumentasi. Adapun instrumen kunci yaitu penulis sendiri.

Selanjutnya langkah-langkah dalam teknik analisis data dalam penelitian ini yaitu: 1) Reduksi Data. Pada langkah ini penulis merangkum, memilih hal-hal yang pokok, memfokukan pada hal-hal yang penting, dicari tema dan polanya. 2) Display Data. Pada langkah ini penulis menggunakan pengkodean data, "Coding" (membuat kode). 3) Kesimpulan/Verifikasi. Pada tahap ini penulis membuat kesimpulan yang menjawab rumusan masalah.

\section{HASIL DAN PEMBAHASAN}

Thomas Lickona (2012 hlm. 82) berpendapat bahwa pendidikan karakter merupakan suatu ikhtiar yang secara sengaja untuk membuat seseorang memahami, peduli dan akan bertindak atas dasar nilai-nilai yang etis. Selanjutnya pendidikan karakter merupakan pendidikan budi pekerti plus yaitu yang melibatkan aspek pengetahuan (cognitive), perasaan (feeling), dan tindakan (action). Kemudian Lickona menyatakan bahwa karakter berkaitan dengan pengetahuan moral (moralknowing), 
perasaan moral (moral feeling) dan tindakan moral (moral behavior). Berdasarkan ketiga komponen tersebut dapat dinyatakan bahwa karakter yang baik didukung oleh pengetahuan tentang kebaikan, keinginan untuk berbuat baik dan melakukan perbuatan kebaikan. Dengan kata lain, komponenkomponen moral tersebut akan membentuk karakter yang baik, tangguh serta unggul. Hal ini sesuai dengan pendapat Saptono (2011 hlm. 23) yang menyatakan bahwa pendidikan karakter upaya yang dilakukan dengan sengaja untuk mengembangkan karakter yang baik (good character) berlandaskan kebajikankebajikan inti (core virtues) yang secara objektif baik bagi individu maupun masyarakat.

Menurut Elkind dan Sweet (dalam Fathurrahman, AA, \& Fenny, 2013 hlm. 16), pendidikan karakter adalah usaha yang sungguh-sungguh untuk membantu orang memahami, peduli, dan bertindak berdasarkan nilai-nilai etika inti. Ketika kita berpikir tentang jenis karakter yang kita inginkan bagi anak-anak kita, jelas bahwa kita ingin mereka bisa menilai apa yang benar,peduli secara mendalam tentang apa yang benar, bahkan dalam menghadapi tekanan dari luar dan godaan dari dalam.

Berdasarkan uraian di atas, dapat disimpulkan bahwa pendidikan karakter adalah pendidikan mengajarkan kebiasaan cara berpikir dan perilaku yang membantu individu untuk hidup dan bekerjasama sebagai keluarga, masyarakat, dan bernegara, dan membantu mereka untuk membuat keputusan yang dapat dipertanggungjawabkan.

Dalam mengajarkan karakter yang baik tentu tidak mudah, untuk memudahkan diperlukan prinsip dalam mengajarkannya. Berdasarkan hal tersebut, Majid \& Dian (2013, hlm. 110-111) berpendapat bahwa dalam pandangan Islam di mana Rasûl Allah dijadikan simbol atau figur keteladanan terdapat beberapa prinsip yang dapat dijadikan pelajaran oleh tenaga pengajar dari tindakan Rasûl Allah dalam menanamkan rasa keimanan dan akhlak terhadap anak, di antaranya: 1) Fokus, yaitu ucapannya ringkas, langsung pada inti pembicaraan, tanpa ada kata yang memalingkan dari ucapannya, sehingga mudah dipahami. 2) Pembicaraannya tidak terlalu cepat sehingga dapat memberikan waktu yang cukup kepada anak untuk menguasainya. 3) Repetisi; senantiasa melakukan tiga kali pengulangan pada kalimat-kalimatnya supaya dapat diingat atau dihafal. 4) Analogi langsung; seperti pada contoh perumpamaan orang beriman dengan pohon kurma, sehingga dapat memberikan motivasi, hasrat ingin tahu, memuji atau mencela, dan mengasah otak untuk menggerakkan potensi pemikiran atau timbul kesadaran untuk merenung dan tafakur. 5) Memperhatikan keragaman anak: sehingga dapat melahirkan pemahaman yang berbeda dan tidak terbatas satu pemahaman saja, dan dapat memotivasi siswa untuk terus belajar tanpa dihinggapi perasaan jemu. 6) Memperhatiakan tiga tujuan moral, yaitu: kognitif, emosional, dan kinetik. 7) Memperhatikan 
pertumbuhan dan perkembangan anak (aspek psikologis/ilmu jiwa). 8) Menumbuhkan kreatifitas anak, dengan cara mengajukan pertanyaa, kemudian mendapat jawaban dari anak yang diajak bicara. 9) Berbaur dengan anak-anak, masyarakat, dan lain sebagainya, tidak eksklusif/terpisah seperti makan bersama mereka, berjuang bersama mereka. 10) Aplikatif: Rasûl Allah langsung memberikan pekerjaan kepada anak yang berbakat. Misalnya, setelah Abu Mahdzurah menjalani pelatihan adzan dengan sempurna yang kita sebut dengan al-Daurah al-Tarbiyah .

William Klipatrick (dalam Majid

\& Dian, 2013, hlm. 31-36) menyebutkan bahwa salah satu ketidakmampuan seseorang berlaku baik meskipun ia telah memiliki pengetahuan tentang kebaikan itu (moral knowing) adalah karena ia tidak terlatih untuk melakukan kebaikan (moral doing). Berangkat dari pemikiran ini maka kesuksesan pendidikan karakter sangat bergantung pada ada tidaknya knowing, loving, dan doing atau acting dalam penyelenggaraan pendidikan karakter.

Di antara lembaga pendidikan yang dapat membantu terbentuknya karakter seseorang adalah pesantren. Pesantren merupakan lembaga pendidikan tertua di Indonesia. Menurut Dhofier (dalam Galba, 1995, hlm. 2) pesantren adalah wadah untuk memperdalam agama dan sebagai pusat penyebaran agama Islam kurang lebih sudah ada pada abad ke-16 M.

Jadi, pesantren dapat diartikan sebagai lembaga pendidikan untuk mendapatkan bimbingan, penghaya- tan, pemahaman, serta pembelajaran ajaran Islam dengan menekankan pentingnya moral agama sebagai pedoman yang dapat diamalkan dalam kehidupan bermasyarakat.

Terlepas dari pernyataan tersebut, pesantren memiliki dua esensi yang merupakan eksistensi pesantren selama ini, yaitu: 1) pesantren sebagai lembaga "agama", dalam hal ini pesantren merupakan media pentransfer nilai, tentunya nilainilai Islami. 2) pesantren sebagai lembaga ilmu. Perpaduan antara keduanya akan melahirkan generasi yang bukan hanya memiliki ilmu pengetahuan/ wawasan yang lebih luas saja, namun akan memiliki pula ketauhidan yang kuat. Selain itu, pesantren juga memiliki fungsi sebagai lembaga sosial yang berpengaruh. Keberadaannya memberikan pengaruh dan warna keberagamaan terhadap masyarakat sekitarnya, tidak hanya di wilayah administrasi pedesaan tetapi sering kali hingga melintasi daerah kabupaten dimana pesantren itu berada(Haedari \& dkk., 2004, hlm. 81).

Dari uraian di atas, dapa
disimpulkan bahwa pesantren
merupakan suatu wadah untuk
mempelajari, menyebarkan, dan mengembangkan ajaran Islam. Pesantren sendiri didirikan atas kesadaran kewajiban dakwah Islamiyah. Dengan kekhasan sebuah pesantren, akan menjadi daya tarik masyarakat untuk nyantri di Pesantren tersebut.

Pesantren sebagai lembaga pendidikan yang bernuansa Islami tentu juga memiliki berbagai peraturan. Peraturan yang ada di pesantren tentu tidak berbeda jauh dengan peraturan di Sekolah umum, akan tetapi di pesantren mungkin peraturannya jauh lebih banyak dan ketat dari pada di Sekolah umum 
karena di pesantren para santri bukan saja menuntut ilmu tetapi juga mondok. Para santri harus mengikuti peraturan yang ada di pesantren, harus disiplin, menghormati dan taat terhadap perintah kyai, ustadzustadzah, dan lain sebagainya. Santri yang mengikuti aturan dapat disebut juga patuh. Patuh atau kepatuhan berarti sikap taat terhadap perintah maupun aturan yang telah ditetapkan. Karakter kepatuhan sangat penting diterapkan di suatu lembaga terutama lembaga pendidikan yang bernuansa Islami seperti di pesantren. Dengan aktivitas yang padat, para santri juga ditekankan agar patuh terhadap aturan yang telah ditetapkan di pesantren. Selanjutnya dengan adanya pelaksanaan karakter kapatuhan yang bagus akan menjadi daya tarik agar pesantren banyak diminati.

Pesantren Buntet Cirebon merupakan pesantren tertua di Jawa yang berdiri sekitar tahun $1758 \mathrm{M}$, yang diprakarsai oleh "Sayyid Muqayyim" atau sering dikenal dengan "Mbah Kyai Muqayyim", merupakan seorang kerabat dan Mufti Kesultanan Cirebon, berarti masih kerabat juga dengan Sunan Gunung Jati. Pada awal berdirinya hingga kemerdekaan RI, pesantren ini sangat mendukung dan bahkan sebagai penerus perjuangan Walisongo (Sunan Gunung Jati).

Jumlah santri di Pesantren ini sekitar kurang lebih 4.000 santri dengan kebanyakan yang nyantri di Pesantren ini berada di luar Cirebon seperti Aceh, Palembang, Jawa Tengah, Jawa Timur, dan dari Jawa Barat selain Cirebon. Pesantren Buntet Cirebon juga memiliki sekolah formal dari tingkat TK hingga Perguruan Tinggi (Akper).

Kemudian berbeda dengan Pondok Pesantren lain, keberadaan Pesantren Buntet Cirebon ini cukup unik karena komunitasnya yang homogen, antara santri dan penduduk asli pesantren ini sulit dibedakan, terutama bila dipandang oleh orang lain. Kemudian baik penduduk asli pesantren ini maupun santri, keberadaan sehari-hari, tidak terlepas dari aktivitas nyantri (ngaji). Bahkan uniknya lagi disebut sebagai perkampungan santri, karena aktivitas sehari-hari diramaikan oleh hingarbingar pelajar yang menuntut ilmu, siang para santri disibukkan dengan belajar di Sekolah formal, dan malam harinya belajar kitab atau diskusi tentang agama di masing-masing kyai sesuai kapasitas ilmunya.

Pesantren tersebut juga memiliki tradisi yang unik juga, misalnya tradisi yang bernama ngaji pasaran. Ngaji Pasaran di Pondok Pesantren Buntet ini digelar 24 jam selama Ramadan. Disebut Ngaji Pasaran sebab dalam pengajian ini mempelajari Alquran dan kitab-kitab yang ada dalam kurikulum pesantren. Tidak hanya santri Pondok Pesantren Buntet, warga dan alumni santri pun sengaja datang ke sini untuk mengaji. Karena ramai maka disebut Ngaji Pasaran.

Terkait dengan pendidikan karakter kepatuhan di Pesantren Buntet, berdasarkan penelitian yang telah dilakukan, penulis dapat jelaskan sebagai berikut:

\section{Perencanan Pendidikan Karakter Kepatuhan di Pesantren Buntet Cirebon}

Perencanaan pendidikan karakter kepatuhan di Pesantren Buntet Cirebon berjalan cukup baik. Hal ini dapat dilihat dari empat tahap yang sudah dilakukan, yaitu: 1) Menentukan filosofis kenapa pentingnya kepatuhan dan terhadap siapa. Pesantren Buntet Cirebon 
memiliki filosofis yang biasa santri sebut dengan "Patuh sampai mati". Filosofis ini ditujukan untuk kyai karena bagi mereka kepatuhan terhadap kyai merupakan hal yang penting. 2) Membuat program. Pesantren Buntet Cirebon memiliki tiga program yang menunjang kepatuhan santri diantaranya: intrakurikuler, ekstrakurikuler, dan pembudayaan. Adapun yang paling menonjol yaitu program pembudayaan. Program intrakurikuler berupa pembelajaran kitab ta'lim muta'alim, program ekstrakurikuler berupa hadroh dan penulisan khat, dan pembudayaan yaitu adanya soan, baul, ngaji pasaran, dan lain sebagainya. 3) Mempersiapkan kebutuhan untuk pelaksanaan program seperti sumber, pengajar, tempat, dan waktu beserta lingkungan.

4) Pelaksanaan program.

\section{Pelaksanaan Pendidikan Karakter Kepatuhan di Pesantren Buntet Cirebon}

Terdapat tiga pelaksanaan pendidikan karakter kepatuhan di Pesantren Buntet Cirebon yaitu: 1) Intrakurikuler. Program intrakurikuler yaitu berupa pembelajaran kitab ta'lim muta'alim yang dilaksanakan setiap hari kecuali selasa dan jumat dari pukul 16.00-17.00 dengan pengajar yang dipilih langsung oleh kyai. Adapun tempatnya yaitu di kelas masing-masing yeng telah disediakan. Alat yang dibutuhkan berupa kitab, meja, hijab antara laki-laki dan perempuan, white board, spidol, dan penghapus. 2) Ekstrakurikuler, berupa kegiatan menulis khat dan hadroh. Kegiatan ini dilaksanakan setiap hari jumat dengan pembimbing ditunjuk sesuai minat dan bakat. Adapun tempatnya yaitu kondisional. 3) Pembudayaan, berupa soan yang dilakukan setiap akan Ujian Nasional, baul yang dilaksanakan setiap satu tahun sekali, ngaji pasaran yang dilaksanakan setiap bulan suci Ramaḍon, dan pembiasaan sehari-hari yaitu ketika kyai sedang berbicara mereka selalu menundukkan kepala, tidak ada yang berani membantah, dan lain sebagainya.

\section{Hasil Pendidikan Karakter Kepatuhan di Pesantren Buntet Cirebon}

Berdasarkan data-data penelitian, penulis menemukan bahwa kepatuhan merupakan aspek yang penting dan bersifat alami. Kepatuhan ini terjadi secara tulus yang terjadi dalam proses yang panjang.terjadi secara tulus dan alami karena: 1) Kepatuhan santri terhadap kyai terjadi secara tulus karena kyai sebagai figur sentral pesantren benar-benar memiliki sifat ikhlas dalam membina santrinya dengan sifat dan akhlakakhlak mulia, tidak terpengaruh oleh kepentingan-kepentingan lain, kecuali Allah. 2) Kasih sayang kyai terhadap santri mampu melandasi seluruh pengembangan pola sikap dan pola tindaknya sehingga setuhan-sentuhan kelembutan dapat mempengaruhi santri secara efektif. 3) Terjadinya pembiasaan yakni kepatuhan santri terhadap kyai itu tumbuh menjadi sutu kebiasaan karena pembinaan kyai dengan akhlak-akhlak baik itu terjadi 
pada suasana psikologis dan lingkungan yang sesungguhnya, bukan lingkungan yang diada-adakan atau dipalsukan.

Selain itu, hal tersebut juga memiliki pengaruh yang besar terhadap perbaikan karakter santri. Terlihat dari berbagai pembiasaan religius (Șalat tepat waktu, Șalat berjamaah, membaca Alquran, dirosah/ngaji kitab, hadroh, batsul masail, dan batsul kutub) yang diaplikasikan dalam kehidupan seharihari maupun hubungan yang baik dengan yang lainnya seperti sikap terhadap kyai (menundukkan kepala ketika berhadapan dengan kyai, patuh terhadap kyai, dan bagi santri laki-laki memiliki kebiasaan mencium tangan kyai), sikap terhadap pengajar (menundukkan kepala ketika pengajar sedang berbicara, patuh terhadap perintah pengajar, bersikap ramah ketika bertemu dengan pengajar), sikap terhadap orang tua (menghormati dan patuh terhadap orang tua), sikap terhadap sesama santri (saling bekerja sama, disiplin, saling menyapa atau memberi senyuman ketika berpapasan dengan sesama santri, dan berdiskusi dengan baik ketika ada masalah, dan lain sebagainya), kemudian sikap terhadap masyarakat (bersikap ramah, saling bekerja sama dan saling menghormati), dan sikap santri terhadap aturan di pesantren yaitu sebagian besar santri patuh pada aturan, dan lain sebagainya.

\section{PENUTUP}

Dari penelitian ini dapat disimpulkan bahwa: Pertama, perencanaan pendidikan karakter kepatuhan di Pesantren Buntet Cirebon berjalan cukup baik. Ini terlihat dari beberapa tahap yang sudah dilaksanakan diantaranya: 1) Menentukan filosofis kenapa pentingnya kepatuhan dan terhadap siapa. Pesantren Buntet Cirebon memiliki filosofis yang biasa santri sebut dengan "Patuh sampai mati”. Filosofis ini ditujukan untuk kyai karena bagi mereka kepatuhan terhadap kyai merupakan hal yang penting.Hal tersebut merupakan keberkahan bagi mereka.2) Membuat program. Pesantren Buntet memiliki tiga program yang menunjang kepatuhan santri diantaranya: intrakurikuler, ekstrakurikuler, dan pembudayaan. Adapun yang paling menonjol yaitu program pembudayaan. 3) Mempersiapkan kebutuhan untuk pelaksanaan program seperti sumber, pengajar, tempat, dan waktu beserta lingkungan. Adapun jika terjadi kerusakan bahanbahan misalnya bangunan Pesantren itu dilakukan renovasi dengan mencari donatur, tetapi biasanya yang menjadi donatur yaitu alumni Pesantren Buntet.Adapun yang membuat keputusan yaitu kyai sepuh. 4) terlaksananya program intrakurikuler, ekstrakurikuler, dan pembudayaan.

Kedua, pelaksanaan pendidikan karakter kepatuhan di Pesantren Buntet Cirebon berjalan cukup baik. Ini terlihat dari trerlaksananya program intrakurikuler, ekstrakurikuler, dan pembudayaan. 
Ketiga, berdasarkan data-data penelitian, penulis menemukan bahwa kepatuhan merupakan aspek penting dan bersifat alami. Kepatuhan ini terjadi secara tulus yang terjadi dalam proses yang panjang. Terjadi secara tulus dan alami karena: 1) Kyai sebagai figur sentral pesantren benar-benar memiliki sifat ikhlas dalam membina santrinya dengan sifat dan akhlakakhlak mulia, tidak terpengaruhi oleh kepentingan-kepentingan lain, kecuali Allah. 2) Kasih sayang kyai terhadap santri mampu melandasi seluruh pengembangan pola sikap dan pola tindaknya sehingga sentuhan-sentuhan kelembutan dapat mempengaruhi santri secara efektif. 3) Terjadinya pembiasaan yakni kepatuhan santri terhadap kyai itu tumbuh menjadi satu kebiasaan karena pembinaan kyai dengan akhlak-akhlak baik itu terjadi pada suasana psikologis dan lingkungan yang sesungguhnya, bukan lingkungan yang diada-adakan atau dipalsukan. 4) Proses pembinaan kepatuhan itu terjadi secara alami yakni kepatuhan santri mengalir dalam proses yang wajar (bukan hasil paksaan). Selain itu, hal tersebut juga memiliki pengaruh yang besar terhadap perbaikan karakter santri. Terlihat dari berbagai pembiasaan religius (Șalat tepat waktu, șalat berjamaah, membaca al-Quran, dirosah/ngaji kitab, hadroh, batsul masail, dan batsul kutub) yang diaplikasikan dalam kehidupan seharihari maupun hubungan yang baik dengan yang lainnya seperti sikap terhadap kyai ( menundukkan kepala ketika berhadapan dengan kyai, patuh terhadap kyai, dan bagi santri laki-laki memiliki kebiasaan mencium tangan kyai), sikap terhadap pengajar (menundukkan kepala ketika pengajar sedang berbicara, patuh terhadap perintah pengajar, bersikap ramah ketika bertemu dengan pengajar), sikap terhadap orang tua (menghormati dan patuh terhadap orang tua), sikap terhadap santri (saling bekerja sama, disiplin, saling menyapa atau memberi senyuman ketika berpapasan dengan sesama santri, dan berdiskusi dengan baik ketika ada masalah, dan lain sebagainya), kemudian sikap terhadap masyarakat (bersikap ramah, saling bekerja sama dan saling menghormati), dan sikap santri terhadap aturan di pesantren yaitu sebagian besar santri patuh pada aturan, dan lain sebagainya. Pesantren Buntet Cirebon tergolong besar dan memiliki manajemen yang cukup bagus dan lengkap meskipun masih banyak yang belum terdokumentasikan.

Rekomendasi penelitian ini yaitu:

Pertama, hendaknya pesantren mendokumentasikan segala pendataan yang ada sebagai optimalisasi penerapan karakter kepatuhan. Selain itu juga akan lebih baik jika peraturanperaturan yang ada di Pesantren tertera di setiap Asrama/Pondok dan di dalam kelas. Hal tersebut merupakan salah satu cara untuk meminimalisir terjadinya pelanggaran.

Kedua, hasil penelitian ini dapat dijadikan masukan dan referensi mengenai implementasi pendidikan karakter kepatuhan yang berkaitan dengan ilmu pendidikan agama Islam 
terutama kaitannya dengan perencanaan, pelaksanaan, dan hasil karakter kepatuhan tersebut.

\section{REFERENSI}

Asmani, J. M. (n.d.). Buku Panduan Internalisasi Pendidikan Karakter di Sekolah.

Damopolii, M. (2011). Pesantren Modern IMMIM: Pencetak Muslim Modern.(S. Syamsudduha, Ed.) Jakarta: Rajawali Pers.

Dhofier, Z. (2011). Tradisi Pesantren : studi pandangan bidup kyai dan visinya mengenai masa depan Indonesia. Jakarta: LP3ES.

Fathurrahman, P., A. S., \& F. F. (2013). Pengembangan Pendidikan Karakter. (A. Gunarsa, Ed.) Bandung: PT Refika Aditama.

Hasanah, A. (2013). Pendidikan Karakter Berperspektif Islam. (E. Dulwahab, Ed.) Bandung: Insan Komunika.

Hidayatullah, F. (2010). Pendidikan Karakter : Membangun Peradaban Bangsa. Surakarta: UNS Press.

Kesuma, D. (2012). Pendidikan Krakter Kajian Teori dan Praktik di Sekolah. Bandung: PT Remaja Rosdakarya.

Koesoema, D. (2007). Pendidikan Karkater Strategi Mendidik Anak di Zaman Global. Jakarta: PT Gramedia.

Kosasih, A. (2011). Model Internalisasi Nilai Drikir pada Ikhwan Tariqat Tijaniah. Disertasi SPs UPI.

Lickona, T. (2012). Educating for Character: How Our Schools Can Teach Respect and Responsibility. Jakarta: Bumi Aksara.
Majid, A., \& D. A. (2013). Pendidikan Karakter Perspektif Islam. (A. S. Wardan, Ed.) Bandung: PT Remaja Rosdakarya.

Milgram, Stanley. (1963). "Behavioral Study of Obedience".Journal of Abnormal and Social Psychology 67.p.371-378.Yale University.(Online). Tersedia: http://www.wordnik. com/words/obedience/ definitions).[10 April 2017].

Mollah, M. K. (2015). Konsep Interaksi Edukatif Dalam Pendidikan Islam Dalam Perspektif Al-Quran. Jurnal Pendidikan Agama IslamVol.3, hal. 249-256.

Mo'tasim. (2015). Fenomena Ta'zir di Pesantren (Analisis Psikologis dan Kelembagaan terhadap Penerapan Ta'zir). Jurnal Pendidikan Agama Islam Vol 3, hal. 310-322.

Mulyasa, E. (2012). Manajemen Pendidikan Karakter. (D. Ispurwanti, Penyunt.) Jakarta: Bumi Aksra.

Rahmawati, A. D. (2015). Kepatuhan Santri Terhadap Aturan Di Pondok Pesantren Modern. Naskah Publikasi (p. 3). Surakarta: Universitas Muhammadiyah Surakarta.

Saptono. (2011). Dimensi-dimensi Pendidikan Karakter Wawasan, Strategi, dan Langkanh Praktik. (Y. Erlangga, \& D. P. P, Eds.) Jakarta: Erlangga Group.

Syahidin. (2015). Aplikasi Model Pendidikan Qurani Dalam Pembelajaran Agama Islam Di Sekolah. Bandung: Latifah Press. 
Tanshzil, S. W. (2012, Oktober 2).

Model Pembinaan Karakter

Pada Lingkungan Pondok

Pesantren dalam Membangun

Kemandirian dan Disiplin

Santri. Jurnal Penelitian Pendidikan

Vol. 13, hal. 6.

Widodo, S. F. (2011). Pendidikan

Karakter dan Implementasinya.

Skripsi tidak diterbitkan. 